\title{
The Effect of Implementation of Smart Board on Iranian Lower-Intermediate EFL Learners' Reading Comprehension and Their Intrinsic Motivation in Reading
}

\author{
Ali Rajabi (MA) \\ English Department, Torbat-e Heydarieh Branch, Islamic Azad University, Torbat-e Heydarieh, Iran \\ alirajabi2015@gmail.com

\section{Hossein Khodabakhshzadeh*}

English Department, Torbat-e Heydarieh Branch, Islamic Azad University, Torbat-e Heydarieh, Iran hkhodabakhshzade@gmail.com

\section{Doi:10.5901/mjss.2015.v6n4s1p281}

\section{Abstract}

\begin{abstract}
Smart board has been found as an effective learning tool in English as foreign language (EFL) reading comprehension. The present study aims at exploring the effects of smart board on reading comprehension and intrinsic motivation to read. Among 90 EFL learners, fifty-two Iranian lower-intermediate EFL learners were selected based on Quick Placement Test (QPT) developed by Oxford University Press and University of Cambridge Local Examinations Syndicate (2001). These participants were randomly assigned in two experimental (smart board) and one control (traditional board) groups. Each group included 26 male EFL students. At the beginning of the study, pretest (Reading Comprehension Test from Key English Test developed by Cambridge ESOL Examination, 2008) was administered to both experimental and control groups. In addition to KET, a translated copy of intrinsic motivation in English reading questionnaire (IMERQ) adopted from Wigfield and Guthrie (1997) was given to these two groups. Throughout the course of 14 sessions (three months), participants in experimental group were taught reading materials from Intro-interchange (Ricahrds, 2005) by using smart board. Participants in control group took benefits from traditional board. Reading materials were the same for both groups. Finally, participants in both groups sat for posttest. Here, both instruments administered at the start of the study, were used as the posttest. Results of t-test indicated that implementation of smart-board significantly improved participants' reading comprehension and their intrinsic motivation to read. These findings provide pedagogical implications for utilizing smart board in EFL context.
\end{abstract}

Keywords: Reading comprehension, smart board, and intrinsic motivation

\section{Introduction}

Smart Board (SB) is a very young teaching and learning tool whose effects on development of reading comprehension were explored in the present study. First produced in 1991 (Shenton \& Pagett, 2008), SBs began to be employed in education in late 1990s (Beeland, 2002). It has been given several names, e.g. Interactive White Board, Electronic White Board or Smart Board (Türel \& Demirli, 2010). It can be defined, as "a touch-sensitive screen that works in conjunction with a computer and a projector" (Smart Technologies Inc., 2006, p. 5). Actually, use of SB in teaching is "not only a current trend but also a major policy of education" (Lan \& Hsiao, \& Tsung-Yen 2011, p. 172).

One of the advantages of smart boards according to Javidi Jelyani, Janfaza, and Soori (2014) is related to their contributions to the enhancement of language learning in the classroom. Employment of smart boards can make the learning and teaching atmosphere more enjoyable, creative, and interesting (Elaziz, 2008). According to Bacon (2011) smart whiteboards can affect learning in a variety of ways. It can increase the learners' engagement in a classroom, motivates the learners and promotes enthusiasm for learning. In fact, smart whiteboards can support learning and can be employed in different learning settings (Chapelle, 2003). Bell (1998) argues that smart boards can assist the students to be more engaged, attentive, and motivated when lessons are presented employing the smart boards. Lee and Boyle (2003) found that "when one can sit and listen to five-year-old children in kindergarten express what is distinct about whiteboard-focused learning ... and how it assists them to learn more, faster and in a more enjoyable and interesting way, ... one senses something rather special is happening."(P.48).

Concerning the contributions of implementation of such technological tools in EFL contexts, intrinsic motivation holds an important place. There is a claim which suggests that computers can enhance extensive reading; develop 
reading fluency and rate; increase intrinsic motivation for reading; and contribute to a coherent curriculum for student achievement (Alsied \& Pathan, 2013). Intrinsic motivation leads to better academic achievements (Renninger, 2000). According to Renninger (2000) the intrinsic motivation plays a crucial role in engaging people while doing the task, and, on the other hand, motivation is an important factor in comprehension of a text (Guthrie \& Scafiddi, 2004). Guthrie and Wigfield (1999), define reading motivation, as "the individual's goals and beliefs with regard to reading" ( p. 199).

The main purpose of this study, nonetheless, is to explore the effects of SB on developing reading comprehension ability among Iranian lower-intermediate EFL learners. Also the effect of the implementation of SB on their intrinsic motivation in reading is explored.

\section{Research Questions}

To achieve the objectives of the present study, the following research questions were posed:

Q1) Does use of Smart Board have any significant effects on Iranian lower-intermediate EFL learners' reading comprehension?

Q2) Does use of Smart Board have any significant effects on Iranian lower-intermediate EFL learners' intrinsic motivation in reading comprehension?

\section{Review of Literature}

Reading comprehension can be defined as to comprehend the content and meaning of a written text. There exist several definitions of reading comprehension but most researchers stress that the process of comprehending material includes connecting the symbols of words to their meanings (Alarfaj\& Alshumaimeri, 2012). Many researchers view reading comprehension as the essence of the process (Sa'ad, 2006) because it is the goal of reading (Gajria, Jitendra, Sood \& Sacks, 2007). Since the goal of the study is to find a way to improve reading comprehension, it is better to define reading and the ability to understand the reading.

Paran (1996) defines reading as an "activity involving constant guesses that are later rejected or confirmed. This means that one does not read all the sentences in the same way, but one relies on a number of words - or 'cues' - to get an idea of what kind of sentence (e.g. an explanation) is likely to follow" (p.25). According to Barros and Carvalho (2007), reading classes are sometimes boring and teachers need to find solutions in order to change the condition. EFL students should be provided with opportunities to be engaged in class activities.

Renninger (2000) views the intrinsic motivation as a crucial factor in engaging people while doing the task, and, on the other hand, motivation is a key factor in comprehension of a text supported by Guthrie and Scafiddi (2004).

In reading classrooms in which the students are provided with opportunities to discuss and take part in class activities, role of teacher as a manager becomes more significant.

Several ways have been introduced as facilitators of EFL students' motivation. Motivation, according to Wu, Yen, and Marek (2011), can be enhanced rapidly, given a positive stimulus, but ability improvement may take significant time and study. Guthrie and Wigfield (1999), defined reading motivation as "the individual's goals and beliefs with regard to reading"( p. 199).

Smart board which is a modern teaching and learning tool whose effects on development of reading comprehension was explored in the present study. It can be defined, as "a touch-sensitive screen that works in conjunction with a computer and a projector" (Smart Technologies Inc., 2006, p. 5).

Recently, new kinds of technological educational tools such as smart-boards are widely used in EFL classrooms. Mathew and Alidmat (2013) in their article " A Study on the Usefulness of Audio-Visual Aids in EFL Classroom: Implications for Effective Instruction" stated that such electronic gadgets as Smart-boards, LCD projectors and Digital Labs empowered teachers to make the teaching-learning process interactive and interesting. University Classrooms with latest technological aids and smart boards should offer a source of inspiration for EFL teachers and learners.

Souhila (2013) explored the effect of employing interactive whiteboards (IWB) as an instructional tool on student engagement. The first finding is students' attitude toward the significance of IWB ability to improve interaction, participation, personal engagement and improved motivation which are considered as positive factors used to determine student engagement for learning. This study stresses on the university students' need for and enthusiastic attitude to the Interactive Whiteboard and its creative teaching methodologies. The second finding is that students also appreciated the IWB learning capacities and recognized its effectiveness in improving their language learning (Souhila, 2013).

Ahmad Al-Saleem (n.d.) investigated the uses of Interactive White Boards in English as Foreign Language (EFL) settings. It was found that the interactive whiteboard is a very innovative and powerful support for acquiring language. 
First of all, it offers a bridge which allows using the properties of computers without breaking communication. Secondly, it may improve new kinds of learning processes. Finally, it provides a very interesting alternative for bringing the Internet into every EFL class.

Al-Sadig (2007) investigated the effect of smart technology in improving the students' presentational skills at AlMajma'ah Community College of King Saud University in 2006. By the end of the scheduled presentations, the majority of the students stated their dissatisfaction with their own performance mainly due to their improper use of the smart board. Their request for additional sessions was approved and a second round of presentations started with better employment of the smart board. The second round turned out to be more productive with respect to time, coverage, communication and computer skills. In the light of the students' performance, Al-Sadig (2007) claims that the students' presentations have largely been improved after employing smart boards.

According to Bacon (2011) smart whiteboards has effects on learning in a variety of ways. Chapell (2003) believes that it increases the level of students' engagement in a classroom, motivates the learners and promotes enthusiasm for learning. In fact, smart whiteboards can support learning and are able to be employed in different learning contexts. Richardson (2002, as cited in Javidi Jelyani et al. 2014), states that "children are always enthusiastic and show heightened motivation when [an interactive whiteboard] is used in the classroom and ... it causes greater attention and enthusiasm to participate and respond" (p.203). According to Salintri, Smith, and Clovis (2002, as cited in Javidi Jelyani et al. 2014), sustained motivation facilitates the process of learning.

A large body of research has focused on the role of smart boards in increasing students' motivation. Levy (2002) found that both teachers and learners perceived smart boards as having significant role in motivating students, focusing their attention and improving whole-class learning.

Javidi Jelyani et al. (2014) in their article "Integration of Smart Boards in EFL Classrooms" conclude that the employment of smart boards in the foreign language classrooms brings an innovative and powerful support for language acquisition. Smart boards, Javidi Jelyani et al. (2014) explain, provide a bridge allowing the learners to take benefits from the features of computers without breaking communication and they support it. In addition, the smart boards may promote new kinds of learning process. Relevant literature also indicated that smart boards have positive effect on students' engagement, motivation, learning styles, and the capability of enhancing the students' understanding (Javidi Jelyani et al. 2014).

\section{Methodology}

\subsection{Participants and Setting}

Among 90 EFL learners, a total number of 52 Iranian lower-intermediate EFL students participated in this study which lasted for 3 months. Their age ranged from 16 to 20. They came from nine classes randomly selected from among sixteen ones at three English language institutes (Bayan, Kian, Shayan) in Torbat-e Heydarieh, Iran. Only males took part in the study. They have studied English for at least 2 years in language institutes. Besides, none of them had the experience of studying or living in English speaking countries.

\subsection{Instrumentation}

In order to achieve the required data the following instruments were given to the participants:

\subsection{Quick Placement Test (QPT)}

To ensure the participants' homogeneity, QPT developed by Oxford University Press and University of Cambridge Local Examinations Syndicate (2001) (grammar, vocabulary, cloze test) was administered to a population consisting of $90 \mathrm{EFL}$ learners. Composed of two parts, part 1 (1-40) and part 2 (41 to 60), QPT contained 60 multiple-choice items. The first part is administered to EFL students of every level of student. However, the second part is administered only to high proficient ones (scoring 31-40 out of 40). In the present study, only the first part was given to the participants. The time allocated for the participants to answer was 40 minutes. Those learners who scored 24 to 30 out of 40 (52 lowerintermediate) were selected as the participants of the study. 


\subsection{Standard Reading Test (Key English Test, KET)}

In order to test the participants' performance in reading comprehension, a standard reading test (KET) developed by Cambridge ESOL Examination (2008) including 4 reading texts was administered as pre and posttest. The test was developed in a multiple-choice format and consisted of 28 items and the time allocated for the test was 30 minutes.

\subsection{Intrinsic motivation in English reading questionnaire}

In order to investigate the effect of the treatment (smart board) on EFL learners' intrinsic motivation in reading comprehension Intrinsic Motivation in English Reading Questionnaire (IMERQ) including reading curiosity (6 items), reading involvement (6 items), importance of reading (2 items) and work avoidance (4 items), adopted from Wigfield and Guthrie (1997), was provided for participants in both groups, both as the pretest and as the posttest. In order to increase the content validity of these items a translated copy (Farsi) was given to the participants and they had to complete in 20 minutes.

\subsection{Materials}

Throughout the course participants in these two groups received materials from the book intro-interchange by Richards (2005). Twelve reading texts of different topics were practiced. In addition to such printed materials, experimental group received some extra reading materials downloaded from the internet. The materials were relevant to the reading contents of the text-book.

\subsection{Procedure}

Fifty-two lower-intermediate EFL learners were selected as the participants of the study, based on QPT, and were randomly assigned to control $(\mathrm{N}=26)$ and experimental $(\mathrm{N}=26)$ groups.

In order to test the participants' performance in reading skills at the start of the study, a test including 4 reading texts was administered as pretest. Participants of both control and experimental groups sat for the pretest.

In addition to the pretest, participants in experimental group were asked to complete a translated copy of Intrinsic Motivation in English Reading Questionnaire (IMERQ) adopted from Wigfield and Guthrie (1997). Throughout the study these participants benefited from smart board in the classroom. Smart board is a digital device which is connected to a computer and will be controlled by the teacher. Using a digital pencil, students were able to write something on the board.. Another advantage of this device is internet access which is of a great importance in recent times. During the reading class EFL teacher was able to search on the internet and download materials relevant to the topic of the reading which was to be taught. In addition, the teacher downloaded pictures and video-clips related to the content of every reading text inside the text-book. The purpose of these digital materials was to create a background or provide the participants with further information about the topic. These participants were also given a time to search on the internet and find relevant materials. For example these participants were provided with materials about certain foods people around the world eat in New Year's Eve.

Participants in control group were asked to complete a translated copy of Intrinsic Motivation in English Reading Questionnaire (IMERQ) adopted from Wigfield and Guthrie (1997). They, however, did not take benefits from any digital devices, and traditional white board was used in this class. The topic and printed materials were the same as the experimental group. These participants received only printed materials. Reading silently, discussing about the text, question-answer process, and simplifying the complex structures, vocabulary and phrases included the techniques commonly used by the teacher. The course lasted for 14 sessions in which reading comprehension was practiced. It is necessary to mention that every session was held per week. Reading passages were adopted from Intro-interchange which is recently taught in language institutes.

Participants in both groups sat for the posttest which was the same as the pretest. In addition to reading test participants in both groups completed IMERQ at the end of the study.

Data obtained from the above mentioned instruments were analyzed by using SPSS (16.0) through conducting independent samples t-test. In addition, descriptive data were presented. 


\section{Results and Discussion}

\subsection{Normality of Tests}

In order to ensure the normality of data, Kolmogorov-Smirnov test was conducted for all data in both quick placement and reading comprehension (Key English Test, KET) tests. The results obtained from the normalizing test are shown in Table 1.

Table 1. Results of Kolmogorov-Smirnov test

\begin{tabular}{llccccc}
\hline & & QPT & preket & postket & motipre & motipost \\
$\mathrm{N}$ & & 52 & 52 & 52 & 52 & 52 \\
Normal Parameters & Mean & 15.2692 & 15.5000 & 17.7500 & 67.8077 & 69.7115 \\
& Std. Deviation & 2.16129 & 2.07223 & 2.10392 & 5.38713 & 5.61628 \\
Most Extreme Differences & Absolute & .122 & .134 & .166 & .180 & .117 \\
& Positive & .122 & .134 & .124 & .180 & .082 \\
& Negative & -.115 & -.092 & -.166 & -.140 & -.117 \\
Kolmogorov-Smirnov Z & & 1.261 & .882 & 1.198 & 1.295 & .841 \\
Asymp. Sig. (2-tailed) & & .083 & .418 & .113 & .070 & .479 \\
a. Test distribution is Normal. & & & & & &
\end{tabular}

Note: QPT stands for Quick Placement Test; preket stands for KET pretest; postket stands for KET posttest; motipre stands for intrinsic motivation questionnaire (pretest); motipost stands for intrinsic motivation questionnaire (posttest).

Null hypothesis of Kolmogorov-Smirnov test is the normality of data. If the obtained P-Value is more than 0.05 then the null hypothesis is accepted. Based on the data in Table 1 the P-Value for all data is more than 0.05, [sig (2tailed) $=.083>.05$ for QPT; sig (2-tailed) $=.418>.05$, for preket; sig (2-tailed) $=.113>.05$ for postket; sig (2-tailed) $=.070>.05$ for motipre, sig (2-tailed) $=.479>.05$, for motipost) so the null hypothesis is accepted that is all data are normal.

\subsection{Results of Groups' Homogeneity Using Quick Placement Test}

Table 2 describes the placement test which categorizes different levels for language proficiency.

Table 2. Results of placement test (QPT)

\begin{tabular}{|c|c|c|c|}
\hline Levels & Paper and pen test score & & Council of Europe Level \\
\hline & Part 1 score out of 40 & Part $1 \& 2$ score out of 60 & \\
\hline 0 beginner & $0-15$ & $0-17$ & A1 \\
\hline 1 elementary & $16-23$ & $18-29$ & $\mathrm{~A} 2$ \\
\hline 2 lower intermediate & $24-30$ & $30-39$ & B1 \\
\hline 3 upper intermediate & $31-40$ & $40-47$ & $\mathrm{~B} 2$ \\
\hline 4 advanced & & $48-54$ & $\mathrm{C} 1$ \\
\hline 5 very advanced & & $54-60$ & $\mathrm{C} 2$ \\
\hline
\end{tabular}

In order to make sure that all participants are homogenous with the same level of language proficiency, Quick Placement Test (QPT) was administered to 90 EFL students. Finally, 52 students whose scores were between24 to 30 out of 40 were selected as the participants of the present study.

\subsection{Results of Homogenizing Test}

Independent samples t-test was conducted to compare the scores obtained by the participants in control and experimental groups in QPT. 
Table 3. Results of independent samples t-test for QPT

\begin{tabular}{|c|c|c|c|c|c|c|}
\hline Group & $\mathrm{N}$ & $\bar{M}$ & SD & $\mathrm{df}$ & $\mathrm{t}$ & Sig(2-tailed) \\
\hline Control & 26 & 26.30 & 1.87 & 50 & .13 & .89 \\
\hline Experimental & 26 & 26.38 & 2.11 & & & \\
\hline
\end{tabular}

As Table 3 shows there is not any statistically significant difference [df=50, $t=.13$, sig(2-tailed)=.89>.05], between control $(\mathrm{N}=26, \mathrm{M}=26.30, \mathrm{SD}=1.87)$ and experimental $(\mathrm{N}=26, \mathrm{M}=26.38, \mathrm{SD}=2.11)$ groups in QPT. Therefore, the homogeneity of the participants was confirmed.

\subsection{Results of independent samples t-test for KET in Pretest}

Independent samples t-test was conducted to compare scores obtained by participants in two groups in the pretest.

Table 4. Results of independent samples t-test for KET in pretest

\begin{tabular}{ccccccc}
\hline Group & $\mathrm{N}$ & $\mathrm{M}$ & $\mathrm{SD}$ & $\mathrm{df}$ & $\mathrm{t}$ & $\mathrm{S}$ Sig(2-tailed) \\
\cline { 1 - 4 } Control & 26 & 15.23 & 2.14 & & .12 & .899 \\
\cline { 1 - 5 } Experimental & 26 & 15.30 & 2.22 & & & \\
\hline
\end{tabular}

As Table 4 shows there is not any statistically significant difference [df=50, $\mathrm{t}=.12$, sig(2-tailed)=.899>.05], between control $(N=26, M=15.23, S D=2.14)$ and experimental $(N=26, M=15.30, S D=2.22)$ groups in pretest which confirms the homogeneity of the participants in two groups.

\subsection{Results of independent samples t-test for KET in Posttest}

To answer the first question" Use of Smart Board does not have any significant effects on Iranian lower-intermediate EFL learners' reading comprehension" independent samples t-test was conducted. Table 5 shows the results.

Table 5. Results of independent samples t-test for KET in posttest

\begin{tabular}{|c|c|c|c|c|c|c|}
\hline Group & $\mathrm{N}$ & $\mathrm{M}$ & SD & df & $\mathrm{t}$ & Sig(2-tailed) \\
\hline Control & 26 & 17.11 & 2.06 & 50 & 2.26 & .028 \\
\hline Experimental & 26 & 18.38 & 1.98 & & & \\
\hline
\end{tabular}

As Table 5 shows participants in experimental group ( $N=26, M=18.38, S D=1.98)$ outperformed significantly [df $=50$, $\mathrm{t}=2.26$, sig=.028<.05] those in control group $(\mathrm{N}=26, \mathrm{M}=17.11, \mathrm{SD}=2.06)$ in posttest. According to the data the first nullhypothesis was rejected and positive effect of implementing smart boards in on EFL students' reading comprehension was confirmed.

\subsection{Results of independent samples t-test for Intrinsic Motivation (Pretest)}

In order to compare participants' scores in intrinsic motivation in reading prior to the implementation of the smart boards, independent samples t-test was conducted (Table 6)

Table 6. Results of independent samples t-test for Intrinsic Motivation (Pretest)

\begin{tabular}{ccccccc}
\hline Group & $\mathrm{N}$ & $\mathrm{M}$ & $\mathrm{SD}$ & $\mathrm{df}$ & $\mathrm{t}$ & Sig(2-tailed) \\
\cline { 1 - 4 } Control & 26 & 67.34 & 4.98 & & .61 & .54 \\
\cline { 1 - 4 } Experimental & 26 & 68.26 & 5.82 & & & \\
\hline
\end{tabular}

As Table 6 shows there is not any statistically significant difference [df=50, $\mathrm{t}=.61$, sig(2-tailed) $=.54>.05]$, between control $(\mathrm{N}=26, \mathrm{M}=67.34, \mathrm{SD}=4.98)$ and experimental $(\mathrm{N}=26, \mathrm{M}=68.26, \mathrm{SD}=5.82)$ groups in intrinsic motivation before the treatment. 


\subsection{Results of independent samples t-test for Intrinsic Motivation (Posttest)}

In order to test the second null-hypothesis "Use of Smart Board does not have any significant effects on Iranian lowerintermediate EFL learners' intrinsic motivation in reading comprehension" independent samples t-test was employed to compare means of two groups in intrinsic motivation posttest.

Table 7. Results of independent samples t-test for Intrinsic Motivation (Posttest)

\begin{tabular}{|c|c|c|c|c|c|c|}
\hline Group & $\mathrm{N}$ & $\mathrm{M}$ & SD & $\mathrm{df}$ & $\mathrm{t}$ & Sig(2-tailed) \\
\hline Control & 26 & 67.88 & 5.68 & 50 & 2.45 & .017 \\
\hline Experimental & 26 & 71.53 & 5.00 & & & \\
\hline
\end{tabular}

As Table 7 shows participants in experimental group $(N=26, M=71.53, S D=5.00)$ gained significantly $[d f=50, t=2.45$, sig=.017<.05] higher scores than those in control group $(N=26, M=67.88, S D=5.68)$ in intrinsic motivation posttest. According to the data the second null-hypothesis was rejected and positive effect of implementing smart boards in on EFL students' intrinsic motivation to read was confirmed.

\section{Discussion}

To achieve the objectives of the present study, three research questions were posed:

Q1) Does use of Smart Board have any significant effects on Iranian lower-intermediate EFL learners' reading comprehension?

Q2) Does use of Smart Board have any significant effects on Iranian lower-intermediate EFL learners' intrinsic motivation in reading comprehension?

Accordingly, the following null-hypotheses were formulated to come up with reasonable results:

H01) Use of Smart Board does not have any significant effects on Iranian lower-intermediate EFL learners' reading comprehension.

H02) Use of Smart Board does not have any significant effects on Iranian lower-intermediate EFL learners' intrinsic motivation in reading comprehension.

Based on the present findings, the first null-hypothesis was rejected confirming positive effects of employing smart boards in EFL reading classrooms. The present finding lent support to what found by Ahmad Al-Saleem (n.d.) indicating that the interactive whiteboard was a very innovative and powerful support for acquiring language. Similarly, Al-Sadig (2007) argued that the students' presentations have largely been improved after employing smart boards.

The second null-hypothesis "Use of Smart Board does not have any significant effects on Iranian lowerintermediate EFL learners' intrinsic motivation in reading comprehension" was also rejected. Based on the findings obtained from data analysis, participants who took benefit from smart board became more intrinsically motivated to read. The present finding was in agreement with Souhila (2013) who explored the effect of employing interactive whiteboards (IWB) on student engagement. IWB was found as a significant tool which enhanced students' interaction, participation, personal engagement and motivation which are viewed as positive factors employed to determine student engagement for learning. Similarly, Soori et al.(2014) found the positive effect of smart board on student engagement ,motivation ,learning styles ,and the capability of enhancing the students understanding.

\section{Conclusion}

The present study explored the effect of implementation of smart board on Iranian lower-intermediate EFL learners' reading comprehension skill and their intrinsic motivation. Results of t-test indicated positive effects of employing smart board as a significant effective learning tool. Based on the present findings implementation of smart board improved both comprehension ability as well as intrinsic motivation to read English texts. Based on the present findings, it can be concluded that smart board can increase students' engagement and participation in class interactions and discussions. Also, smart board can create an enjoyable environment where students feel relaxed and interested in reading. Javidi Jelyani et al. (2014) argue that one of the advantages of smart boards is associated with their contributions to improvement of language learning in the classroom. Elaziz (2008) believes that employment of smart boards makes the learning and teaching atmosphere more enjoyable, creative, and interesting. Smart board can increase the learners' engagement in a classroom, motivates the learners and promotes enthusiasm for learning. In fact, smart whiteboards can 
support learning and can be employed in different learning settings (Chapelle, 2003).

EFL teachers need to equip their classrooms with technological tools such as smart board to shift from teachercentered classrooms to student-centered ones in which they are more engaged and motivated in activities and discussions. Also, they need to learn how to use such tools. EFL teachers' lack of required information about technology use results in negative outcomes in class.

EFL students need to prepare themselves for modern language classrooms in which computer and internet replace the teacher. As a result innovative teaching and learning techniques replace the traditional ones which were based on blackboard, pen and paper. They need to receive required trainings and increase their information about technological tools to practice out of the class. They will become aware of the fact that they will be able to learn independently from their teacher thanks to technology.

Curriculum designers will benefit from the present findings in developing new materials. They should develop innovative textbooks (digital books) to increase students' motivation and engagement. They should encourage use of smart-board in language classrooms to enhance students' achievement.

\section{References}

Ahmad Al-Saleem, B.I.A. (n.d.). The Interactive Whiteboard In English As A Foreign Language (EFL) Classroom. European Scientific Journal, 8(3), 126-134.

Alarfaj, A., \& Alshumaimeri, Y.(2012). The effect of a suggested training program on reading speed and comprehension of Saudi female university students. Procedia - Social and Behavioral Sciences 31, 612 - 628.

Al-Sadig, Y.A. (2007). The Role of Smart Boards in Enhancing Students' Oral Presentations:The Case of Al-Majma'ah Community College, King Saud University. Retrieved from: www.academia.edu.

Alsied, S.M., \& Pathan, M.M. (2013). The Use of Computer Technology in EFL Classroom: Advantages and Implications. IJ-ELTS: International Journal of English Language \& Translation Studies, 1(1), 61-71.

Bacon, D. (2011). The interactive whiteboard as a force for pedagogic change. Information Technology in Education Journal,15-18.

Barros, A.C., Carvalho, A.A. (2007). From a WebQuest to a Reading Quest: learners' reactions in an EFL extensive reading class. Interactive Educational Multimedia, (15). 37-51.

Beeland, W. D. (2002). Student engagement, visual learning and technology: Can interactive whiteboards help?. Artmanscrpt.1(1). Online available at: http://chiron.valdosta.edu/are/.

Bell, M.A. (1998). Teachers' Perceptions Regarding the Use of the Interactive Electronic Whiteboard in Instruction. Retrieved from www.smarterkids.org/research/paper6.asp, Baylor University.

Chapelle, J. (2003). How Is the Interactive Whiteboard Being used in Primary School. Becta Research Bursary. Retrieved from www.virtuallearning.org.uk/whiteboards/IFS_interactive whiteboards_in_the primary_school.pdf.

Elaziz, F. (2008). Attitudes of students and teachers towards the use of interactive whiteboards in EFL classrooms. Unpublished master' thesis, Bilkent University, Ankara.

Gajiia, M., Jitendra, A., Sood, S., \& Sacks, G. (2007). Improving comprehension of expository text in students with LD. Journal of learning disabilities, 40(3), 210-225.

Gérard, F.,\& Widener, J. (n.d.). A smarter way to teach foreign language: the smart board ${ }^{\mathrm{TM}}$ interactive whiteboard as a language learning tool. Available at: smarttech.com.

Guthrie, J.T., \& scafiddi, N.T. (2004). Reading comprehension for information text: Theoretical meanings, Developmental patterns, and benchmarks for instruction. In Guthrie, J.T, Wigfield, A. \& Perencevich, K.C (Eds). Motivating reading comprehension. (pp. 225249). London: Lawrence Erlbaum associates.

Guthrie, J. T., \& Wigfield, A. (1999). How motivation fit into a science of reading. Scientific Science of Reading, 3 (3), 199-205.

Javidi Jelyani, S., Janfaza, A.,\& Soori, A.(2014). Integration of Smart Boards in EFL Classrooms. International Journal of Education \& Literacy Studies, 2 (2), 20-23.

Lan, Tian-Syung, \& Hsiao, Tsung-Yen (2011). A study of elementary school students' viewpoints on interactive whiteboard. American Journal of Applied Sciences, 8(2), 172-176.

Lee, M., \& Boyle, M. (2003). The Educational Effects and Implications of the Interactive Whiteboard Strategy of Richardson Primary School: A Brief Review. Retrieved from www.richardsonps.act.edu. au/RichardsonReview_Grey.pdf.

Mathew, N.G.,\& Alidmat, A.O.H. (2013). A Study on the Usefulness of Audio-Visual Aids in EFL Classroom: Implications for Effective Instruction. International Journal of Higher Education, 2(2), 86-92.

Paran, A. (1996). Reading in EFL: facts and fictions. ELT Journal, 50 (1), 25-34.

Renninger, K. A. (2000). Individual interest and its implications for understanding intrinsic motivation. In C. Sansone \& J. M. Harackiewicz (Eds), Intrinsic and Extrinsic motivation: The search for optimal motivation and performance (pp. 373-404). San Diego, CA: Academic Press.

Sa'ad, M. A. I. (2006). Weakness in Reading and Learning styles. Alexandria: Dr Elwafaá Publishing.

Shenton, A., \& Pagett, L. (2008). From 'bored' to screen: the use of the interactive whiteboard for literacy in six primary classrooms in England. Literacy, 41(3), 129-136. 
Smart Technologies Inc. [SMART]. (2006). Interactive whiteboards and learning improving student learning outcomes and streamlining lesson planning. White Paper, Retrieved from:. http://downloads01.smarttech.com.

Souhila, B. (2013). We Need Change! The Interactive White Board in the EFL Context. Academic Journal of Interdisciplinary Studies, 2(3), 379-384.

Türel, Y. K., \& Demirli, C. (2010). Instructional interactive whiteboard materials: Designers' perspectives. Procedia Social and Behavioral Sciences, 9, 1437-1442.

Türel, Y.K.,\& Johnson, T.E. (2012). Teachers' Belief and Use of Interactive Whiteboards for Teaching and Learning. Educational Technology \& Society, 15 (1), 381-394.

Wu, W.-C. V., Yen, L. L., \& Marek, M. (2011). Using Online EFL Interaction to Increase Confidence, Motivation, and Ability. Educational Technology \& Society, 14 (3), 118-129. 